\title{
Association Between Magnetic Resonance Imaging Exposure During Pregnancy: Fetal and Childhood Outcomes
}

\author{
Gebelikte Manyetik Rezonans Görüntüleme Maruziyetinin Fetal Dönemde ve \\ Çocukluk Çağındaki Sonuçları
}

Özge Uygun

Istanbul University Istanbul Faculty of Medicine, Department of Neurology, Istanbul, Turkey

Keywords: Pregnancy, magnetic resonance imaging, congenital anomaly, visual and hearing loss

Anahtar Kelimeler: Gebelik, manyetik rezonans görüntüleme, konjenital anomali, işitme ve görme kaybı

\section{Association Between Magnetic Resonance Imaging Exposure During Pregnancy: Fetal and Childhood Outcomes}

The effects of ionized radiation on the fetus during pregnancy have become remarkable because imaging modalities are frequently used today. The clinical approach is to use the least amount of radiation, and as much as possible, to use imaging methods that do not contain radiation [e.g., ultrasonography, magnetic resonance imaging (MRI)].

Although MRI seems safe especially in the second and third trimesters, it is thought that radiofrequency waves and high acoustic media may negatively affect fetal tissues in the first trimester, and especially in the organogenesis period. The effectiveness of MRI increases with gadolinium. However, it is known that gadolinium is transmitted to fetal blood with maternal serum, excreted to amniotic fluid from the fetal circulation, and then recirculated. The risk for fetal nephrogenic systemic fibrosis is believed to increase secondary to this situation. Therefore, physicians must be aware that contrast agent should not be given and more attention should be paid when MRI is performed in pregnancy.

In a retrospective study conducted in Ontario between April 2003 and March 2015 (1), two groups were created with pregnant women aged over 16 years and under 50 years who had completed the 20th gestational week, using the first child in multipara pregnancies. The mothers and babies were healthy.

Pregnant women who were exposed to MRI in the first trimester of gestation (2 to 14 weeks' gestation) were included in the first group, and patients who were exposed to contrastenhanced MRI in any period from the second gestational week to the second prenatal day were included in the study. Potential results for the first group were listed as congenital anomalies without accompanying chromosomal anomalies, neoplasms, loss of vision, and loss of hearing. The relevant conditions were determined as rheumatic, inflammatory, infiltrative diseases (arthritis, vasculitis, bone diseases, dermatitis, connective tissue calcification) and every type of condition related with stillbirth/abortion.

A total rate of 19/1,000 stillbirths/abortions was seen in the first group, which was not different from the normal population. The most common conditions occurring in the first trimester included anomalies associated with the circulatory system, digestive system, and musculoskeletal system, and this situation was not correlated with the time of exposure to MRI or the anatomic location from which the MRI was taken. Although neoplasm, congenital anomalies, and loss of hearing were not significant in the first $5-10^{\text {th }}$ gestational weeks, loss of vision was slightly higher (HR: 2.28, RR: 2.7/1000). A rate of stillbirth/abortion of $7 / 1,000$ was found in the second group with nephrogenic systemic fibrosis being more significant

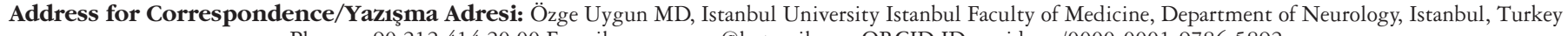
Phone: +90 2124142000 E-mail: ozz_uygun@hotmail.com ORCID ID: orcid.org/0000-0001-9786-5892

Received/Geliş Tarihi: 22.03.2017 Accepted/Kabul Tarihi: 29.04.2017

${ }^{\circ}$ Copyright 2017 by Turkish Neurological Society

Turkish Journal of Neurology published by Galenos Publishing House.
} 
in the contrast-enhanced MRI group compared with the group without exposure to MRI. In addition, rheumatologic, inflammatory, and infiltrative skin lesions were more common than the group without MRI exposure. However, no significant difference was seen in congenital abnormalities when compared with the normal population.

In conclusion, with the clinical view, pregnancy is not a contraindication for MRI. MRI exposure does not carry a significant risk for fetal anomalies compared with the normal population in the first trimester. Nevertheless, gadolinium- containing MRI was found to be associated with the risk for rheumatologic, inflammatory and infiltrative skin lesions, and still birth/abortion. Therefore, performing of contrast-enhanced MRI should be avoided during pregnancy.

\section{Reference}

1. Ray JG, Vermeulen MJ, Bharatha A, Montanera WJ, Park AL. Association Between MRI Exposure During Pregnancy and Fetal and Childhood Outcomes. JAMA 2016;316:952-961. 